\title{
Lower Back Problems and Work-Related Risks in a South African Manganese Factory
}

Bernard van Vuuren ${ }^{1,2}$, Hendrik J. van Heerden ${ }^{1}$, Piet J. Becker ${ }^{3,4}$, Evert Zinzen ${ }^{5}$ and Romain Meeusen ${ }^{2}$

(1) Department of Biokinetics, Sport and Leisure Sciences, LC de Villiers Sport Centre, University of Pretoria, South Street, Hatfield, Pretoria, 0002, South Africa

(2) Department Human Physiology \& Sports Medicine, Faculty LK, Vrije Universiteit Brussel, Pleinlaan 2, 1000 Brussels, Belgium

(3) Biostatistics Unit, Medical Research Council of South Africa, Private Bag X 385, Pretoria, South Africa

(4) Department of Clinical Epidemiology, Faculty of Health Sciences, University of Pretoria, Pretoria, South Africa

(5) Department of Movement Education and Sportstraining, Faculty LK, Vrije Universiteit Brussel, Pleinlaan 2, 1000 Brussels, Belgium

\section{Bernard van Vuuren}

Email: bernard.vanvuuren@up.ac.za

\begin{abstract}
An analytical cross-sectional epidemiological study carried out among 109 manganese plant workers aimed to examine the prevalence and association between lower back problems (LBP) and occupational risk factors. Outcome was defined using a guided questionnaire and a functional rating index. Exposure to occupational risk factors was determined using self-reported questionnaires and workstation analyses. Multivariate logistic regression analyses indicated significant adjusted odds ratios (OR) for prolonged $90^{\circ}$ trunk flexion (OR 2.16; CI 1.15-4.05); manual handling (1.89; $1.17-$ $3.08)$; load carriage $(1.54 ; 1.08-2.19)$; and lifting (4.61; 1.37-15.47). The findings
\end{abstract}


illustrate regional and occupational specifics of risk for LBP, and indicate that selfselection or adaptation to task-specific demands could possibly lead to observations of ergonomically relevant risk factors, which do not necessarily yield statistically significant associations with LBP. The findings further support multi-modal preventative approaches.

\section{Introduction}

Back problems affects millions of people worldwide, and mankind has suffered from back problems for at least as long as documented records exist. In national health care systems throughout the world back pain is common, often poorly managed, and very costly - both in terms of direct treatment expenses, and indirect costs due to disability and lost productivity [1]. Lower back problems (LBP) are common in industrialised countries, with literature reporting various prevalence and incidence figures, which indicate a universal and relevant problem [2-5]. The cumulative international incidences of LBP during 1970 and 1992 were 38 and 43\%, respectively [6], which indicates the rising nature of LBP.

In spite of a number of epidemiological studies over the past three decades, the etiology and risk factors of work-related back disorders are not well understood, and the literature is replete with apparent contradictions. Research communities in the 1980s focussed on biomechanical factors, in the 1990s the focus changed towards psychosocial factors, and at the start of the new millennium most funding was spent on understanding genetic and biochemical sources of LBP [7]. It appears thus that certain causal methods of investigation have been in and out of vogue for periods of time, at the expense of a balanced approach to understanding the causality of LBP. Another point of concern is that although literature on the epidemiology of LBP is accumulating, for the most part studies are restricted to high-income countries, which comprise less than $15 \%$ of the world's population. Little is known about the epidemiology of LBP in the rest of the world [8].

It is currently commonly accepted, however, that back disorders are multifactorial in origin and may be associated with both occupational and nonwork-related factors and characteristics. Psychosocial factors have also been associated with both work- and nonwork-related back disorders [9-11]. The most frequently reported occupational risk factors are heavy physical work; frequent bending, twisting, lifting, pulling, and 
pushing; repetitive work; forceful movements; static postures like prolonged sitting, awkward postures and whole-body vibrations [12-23]. While the focus of this manuscript is on physical occupational risks, work related psychosocial risk factors that have been identified include anxiety, depression, job dissatisfaction, and mental stress $[24,25]$.

The degree to which occupational exposure poses various risk factors for the development of low back disorders is another interesting question that remains unanswered. Everyone has some level of baseline risk for LBP. The risk can be increased by personal factors (genetics, psychosocial, biomechanical etc.) but it may also be increased by work exposure. The question is thus not so much whether work can lead to back pain; rather the question is how much exposure to certain factors might increase the risk of experiencing LBP to an unacceptable level [7].

Studies of worksite-based LBP are thus needed to explicate the association between work tasks and the onset of LBP [26], and how exposure to certain work factors might predispose the risk of developing LBP. Although cross-sectional studies cannot answer all of the posed questions and problems, it does increase the understanding of this complex phenomenon, particularly in unexplored populations at risk. The African industrial setting, which is often reliant on manual labour, is one such population. The goal of this study was to examine the prevalence and association between LBP and occupational risk factors a South African Manganese industry.

\section{Methods}

\section{Subjects and design}

The design entailed an analytical cross-sectional study among a group of 109 workers in a Manganese factory. The process of manganese production via electrolysis requires that plates be removed from acid cells and placed on monorails (cell stripping) and moved to an area where the manganese residue is removed or "knocked off" with rubber hammers (knock-off bins). (See Table 1 for demographic data). Eighty-two (75\%) of the subjects studied worked in cell houses, primarily performing hard manual labour during cell stripping and knock-off bin (KOB) work. The remaining 27 (25\%) workers worked in the metal handling houses, performing various tasks such as forklift driving, light packing and process control work. A 
positive feature of this study was the involvement of 109 of the 113 workers, thus eliciting a high rate of participation (96\%) and ensuring an in-depth analytical study. Table 1 Characteristics of the study population $(n=109)$

\begin{tabular}{|l|l|}
\hline \multicolumn{1}{|c|}{ Characteristics } & \multicolumn{1}{c|}{$\boldsymbol{M}( \pm \mathbf{S D})$} \\
\hline Age $(\mathrm{Yr})$ & $35.52(9.29)$ \\
\hline Work exposure (Yr) & $7.78(6.99)$ \\
\hline Gender & $100 \%$ Males \\
\hline
\end{tabular}

\section{Measurements and instruments}

\section{Case definition}

The functional rating index (FRI) comprising 10 items developed and validated by Feise and Menke [27] to assess the extent to which LBP affects daily activities, was applied to determine stringent case definition. The FRI index score was achieved by simply summing up the equality weighted scores of 10 items relating to pain intensity, sleep, personal care, travel (driving etc.), work, recreation, frequency of pain, lifting, walking and standing, dividing by the total number of possible points, and multiplying by one hundred percent. The higher the number, the higher the perceived dysfunction and pain. The FRI score was calculated as follows: (total score $/ 40$ ) $\times 100 \%$. A FRI of $\geq 30 \%$ perceived disability was used in the analyses as a stringent definition for LBP, and the mere presence of self-reported back pain at the time, was used as an inclusive definition to record cases of LBP.

\section{Occupational risks}

To measure occupational exposure, the Occupational Risk Factor Questionnaire (ORFQ) developed and validated via test-retest and inter-rater reliability statistics by Halpern and co-workers [28] comprising 26 self-report items was utilized. Five categories of risk factors that may be associated with LBP, viz. work organisation, trunk posture, handling activities, body position and environmental demands were thus probed. Accordingly responses describing the duration of exposure to occupational risks in the work setting (items 6-22) as being "half the time" or more were classified as exposed cases. Similarly responses describing the frequency of lifting tasks (items 23-26) as being 11-30, or more, times per hour were classified as exposed cases. 
To measure lifting specific risk, the South African developed LiftRISK software programme [29] was utilized. LiftRISK assesses the lifting risk associated with each of 4 task-related parameters namely object mass, frequency of lifting, horizontal reach and vertical distance (stoop and stretch), and assigns an appropriate rating of risk potential, named the Task Inherent Risk (between 2 and 8). A rating of higher than 5 is seen as high risk.

\section{Procedures}

To ensure reliability of the data and representation, the questionnaires were administrated during guided interview sessions, with anonymity being assured. The study was furthermore conducted in accordance with the declaration of Helsinki, with the informed consent of all parties and the necessary Ethics committee approval. The FRI is known for its reliability, validity, and responsiveness [27]. This was confirmed in the study population, with high internal consistency (Cronbach alpha values) being recorded (CA 0.95). Good internal consistency was recorded for the ORFQ with a Cronbach alpha value of 0.83 . Similarly high test - retest reliability (Frequency of differences $<20 \%$ ) for the FRI and ORFQ was recorded in the pilot study. Additional systematic observational workstation analyses were performed on site to determine lifting tasks related risk variables (reaching distances, stooping heights, lifting frequencies and lifting styles).

\section{Statistical analyses}

Non-linear or asymmetric scales were used in the ORFQ. This rationale was based on psychophysical and epidemiological reasons. Sensory threshold curves and perceived exertions have been shown to follow non-linear functions that require finer resolution in the lower and middle ranges [30]. The exposures at the higher end are quite rare, thus affecting the logistics of epidemiological validation studies [31]. Conditions that persist for more than half the work time may also be an obvious risk for the development of musculoskeletal disorders [32]. It is thus important to know the thresholds rather than the maximal tolerance for developing LBP [33]. For the assessment of risk factors, crude odd ratios (OR) were derived directly from $2 \times 2$ tabulations, while adjusted ORs followed from multivariate analyses, adjusting for age, smoking habits, job description, and years of work exposure as possible confounders. In the statistical analyses, testing was done at the 0.05 level of significance. The ORs described the relative effect, while the confidence intervals described the precision of the estimate. Where appropriate, and where the data was of 
a ratio nature, standard descriptive statistics (means and standard deviations) were employed. Where appropriate, significant associations between nominal categorical variables were tested for using the chi-square test. The statistical data analysis was performed using Stata Release 8, Stata Press, STATA CORPORATION, College Station, Texas. Copyright 1985-2003.

\section{Results}

Using an inclusive definition (presence/absence of LBP), lifetime and annual prevalence of LBP were 71.6 and $69.8 \%$ respectively, with month and point prevalence being 55.0 and $37.6 \%$, respectively. Using the FRI, as a stringent definition, to measure perceived dysfunction and pain, $29.4 \%$ of the workers reported a $30 \%$ or higher disability. Comparing the prevalence of LBP between workers of the cell houses ( $n=82$; hard manual labour) with workers of the metal handling houses ( $n=27$; various tasks) indicated higher prevalence of LBP for the cell house workers using both inclusive (39.02\% vs. $30.77 \%)$ and stringent definitions (36.37\% vs. $11.54 \%$ ), respectively. Prevalence figures of different work tasks can be seen in Table 2.

Table 2 Prevalence of lower back problems for different work tasks

\begin{tabular}{|l|l|l|l|l|}
\hline \multicolumn{1}{|c|}{ Work task (n= 109) } & $\begin{array}{r}\text { Point prevalence (inclusive } \\
\text { definition) }\end{array}$ & $\begin{array}{r}\text { Point prevalence (stringent } \\
\text { definition) }\end{array}$ \\
\hline \hline & Prevalence (\%) & CI 95\% & Prevalence (\%) & CI 95\% \\
\hline Cell strippers (77) & 40.26 & $29-51$ & 36.36 & $25-47$ \\
\hline KOB workers (5) & 20.00 & $0-76^{\mathrm{a}}$ & 20.00 & $0-76^{\mathrm{a}}$ \\
\hline Total cell house workers & 39.02 & $29-50$ & 30.77 & $21-41$ \\
(82) & 20.00 & $0-76^{\mathrm{a}}$ & 0 & $0-74^{\mathrm{a}}$ \\
\hline Stabiliser (5) & 42.86 & $0-92^{\mathrm{a}}$ & 28.57 & $0-76^{\mathrm{a}}$ \\
\hline LO Packer (7) & 60.00 & $0-128^{\mathrm{a}}$ & 20.00 & $\mathrm{NA}^{\mathrm{b}}$ \\
\hline Nitrider (5) & 28.57 & $0-74^{\mathrm{a}}$ & 0 & $\mathrm{NA}^{\mathrm{b}}$ \\
\hline Powder mill operator (7) & $28 A^{\mathrm{b}}$ & 0 & \\
\hline Process controller (3) & 0 & & & \\
\hline
\end{tabular}




\begin{tabular}{|l|l|l|l|l|}
\hline \multicolumn{1}{|c|}{ Work task ( $\boldsymbol{n}=\mathbf{1 0 9})$} & $\begin{array}{r}\text { Point prevalence (inclusive } \\
\text { definition }\end{array}$ & $\begin{array}{r}\text { Point prevalence (stringent } \\
\text { definition) }\end{array}$ \\
\hline \hline & Prevalence (\%) & CI 95\% & Prevalence (\%) & CI 95\% \\
\hline \begin{tabular}{l|l|l|l|} 
Total metal handling \\
house workers (27)
\end{tabular} & 30.77 & $13-48$ & 11.54 & $0-74^{\mathrm{a}}$ \\
\hline
\end{tabular}

${ }^{\mathrm{a}}$ Confidence intervals are broad, due to small sub sample numbers. This however is true to the nature of the specific plant.

${ }^{\mathrm{b}}$ Not applicable. 
Table 3 presents a summary statistics of the study findings.

Table 3 Summary statistics of study findings

\begin{tabular}{|c|c|c|c|c|c|c|c|c|c|c|}
\hline \multirow[t]{2}{*}{ Variables } & \multicolumn{2}{|c|}{$\begin{array}{c}\text { Chi square } \\
\text { analyses }\end{array}$} & \multicolumn{4}{|c|}{ Univariate analyses crude ORs } & \multirow{2}{*}{\begin{tabular}{|c|}
$\begin{array}{c}\text { Multivariate } \\
\text { analyses adjusted } \\
\text { ORs }\end{array}$ \\
$\begin{array}{c}\text { OR Inclusive } \\
\text { definition }\end{array}$ \\
\end{tabular}} & \multirow[b]{2}{*}{$\begin{array}{c}\text { CI } \\
95 \%\end{array}$} & \multirow[b]{2}{*}{$\begin{array}{c}\text { OR Stringent } \\
\text { (FRI) } \\
\text { definition }\end{array}$} & \multirow[b]{2}{*}{$\begin{array}{r}\text { CI } \\
95 \%\end{array}$} \\
\hline & $\begin{array}{c}\text { FRI } \\
<30 \%\end{array}$ & $\begin{array}{c}\text { FRI } \\
>30 \%\end{array}$ & $\begin{array}{c}\text { Crude OR } \\
\text { Inclusive } \\
\text { definition }\end{array}$ & $\begin{array}{c}\text { CI } \\
95 \%\end{array}$ & $\begin{array}{c}\text { Crude OR } \\
\text { Stringent (FRI) } \\
\text { definition }\end{array}$ & $\begin{array}{c}\text { CI } \\
95 \%\end{array}$ & & & & \\
\hline $\begin{array}{l}45^{\circ} \text { Trunk } \\
\text { flexion }\end{array}$ & $\begin{array}{l}70.13 \% \\
(54 / 77)\end{array}$ & $\begin{array}{l}78.50 \% \\
(28 / 32)\end{array}$ & 2.21 & $\begin{array}{l}0.71- \\
6.82\end{array}$ & 2.98 & $\begin{array}{l}0.92- \\
9.71\end{array}$ & 1.36 & $\begin{array}{l}0.92- \\
2.03\end{array}$ & 1.24 & $\begin{array}{l}0.78- \\
1.97\end{array}$ \\
\hline $\begin{array}{l}90^{\circ} \text { Trunk } \\
\text { flexion }\end{array}$ & $\begin{array}{l}66.23 \% \\
(51 / 77)\end{array}$ & $\begin{array}{l}93.75 \\
(30 / 32)^{a}\end{array}$ & 3.99 & $\begin{array}{l}1.23- \\
12.95^{\mathrm{a}}\end{array}$ & 7.65 & $\begin{array}{l}1.57- \\
37.15^{\mathrm{a}}\end{array}$ & 3.09 & $\begin{array}{l}1.49- \\
6.41^{\mathrm{a}}\end{array}$ & 2.16 & $\begin{array}{l}1.15- \\
4.05^{\mathrm{a}}\end{array}$ \\
\hline $\begin{array}{l}\text { Twisting }\left(45^{\circ}\right) \\
\text { and bending of } \\
\text { trunk }\end{array}$ & $\begin{array}{l}84.42 \% \\
(65 / 75)\end{array}$ & $\begin{array}{l}96.88 \% \\
(31 / 32)\end{array}$ & 1.71 & $\begin{array}{l}0.41- \\
7.09\end{array}$ & 5.72 & $\begin{array}{l}0.68- \\
48.01\end{array}$ & 1.14 & $\begin{array}{l}0.71- \\
1.82\end{array}$ & 1.38 & $\begin{array}{l}0.73- \\
2.62\end{array}$ \\
\hline $\begin{array}{l}\text { Bulky manual } \\
\text { handling }\end{array}$ & $\begin{array}{l}9.09 \% \\
(7 / 77)\end{array}$ & $\begin{array}{l}9.38 \% \\
(3 / 32)\end{array}$ & 2.57 & $\begin{array}{l}0.47- \\
14.07\end{array}$ & 1.03 & $\begin{array}{l}0.25- \\
4.31\end{array}$ & 1.89 & $\begin{array}{l}1.17- \\
3.08^{\mathrm{a}}\end{array}$ & 1.41 & $\begin{array}{l}0.86- \\
2.32\end{array}$ \\
\hline $\begin{array}{l}\text { Single handed } \\
\text { manual handling }\end{array}$ & $\begin{array}{l}5.19 \% \\
(4 / 77)\end{array}$ & $\begin{array}{l}9.38 \% \\
(3 / 32)\end{array}$ & 1.62 & $\begin{array}{l}0.27- \\
9.62\end{array}$ & 1.89 & $\begin{array}{l}0.39- \\
9.10\end{array}$ & 1.77 & $\begin{array}{l}1.09- \\
2.89^{\mathrm{a}}\end{array}$ & 1.28 & $\begin{array}{l}0.80- \\
2.07\end{array}$ \\
\hline Unstable manual & $3.90 \%$ & $3.13 \%$ & 1.59 & 0.14 & 0.80 & $0.79-$ & 1.69 & $1.04-$ & 1.45 & $0.83-$ \\
\hline
\end{tabular}




\begin{tabular}{|c|c|c|c|c|c|c|c|c|c|c|}
\hline \multirow[t]{2}{*}{ Variables } & \multicolumn{2}{|c|}{$\begin{array}{l}\text { Chi square } \\
\text { analyses }\end{array}$} & \multicolumn{4}{|c|}{ Univariate analyses crude ORs } & \multirow{2}{*}{\begin{tabular}{|c|}
$\begin{array}{c}\text { Multivariate } \\
\text { analyses adjusted } \\
\text { ORs }\end{array}$ \\
$\begin{array}{c}\text { OR Inclusive } \\
\text { definition }\end{array}$ \\
\end{tabular}} & \multirow[b]{2}{*}{$\begin{array}{c}\text { CI } \\
95 \%\end{array}$} & \multirow[b]{2}{*}{$\begin{array}{c}\text { OR Stringent } \\
\text { (FRI) } \\
\text { definition }\end{array}$} & \multirow[b]{2}{*}{$\begin{array}{r}\text { CI } \\
95 \%\end{array}$} \\
\hline & $\begin{array}{c}\text { FRI } \\
<30 \%\end{array}$ & $\begin{array}{c}\text { FRI } \\
>30 \%\end{array}$ & $\begin{array}{l}\text { Crude OR } \\
\text { Inclusive } \\
\text { definition }\end{array}$ & $\begin{array}{c}\text { CI } \\
95 \%\end{array}$ & \begin{tabular}{|c|} 
Crude OR \\
Stringent (FRI) \\
definition
\end{tabular} & $\begin{array}{c}\text { CI } \\
95 \%\end{array}$ & & & & \\
\hline handling & $(3 / 77)$ & $(1 / 32)$ & & 18.71 & & 8.04 & & $2.75^{\mathrm{a}}$ & & 2.56 \\
\hline $\begin{array}{l}\text { Pushing and } \\
\text { pulling }\end{array}$ & $\begin{array}{l}68.83 \% \\
(53 / 77)\end{array}$ & $\begin{array}{l}90.63 \% \\
(29 / 32)^{\mathrm{a}}\end{array}$ & 1.61 & $\begin{array}{l}0.53- \\
4.87\end{array}$ & 4.38 & $\begin{array}{l}1.16- \\
16.45^{\mathrm{a}}\end{array}$ & 1.55 & $\begin{array}{l}0.91- \\
2.68\end{array}$ & 1.59 & $\begin{array}{l}0.84- \\
2.99\end{array}$ \\
\hline $\begin{array}{l}\text { Carrying 5- } \\
15 \text { kg objects }\end{array}$ & $\begin{array}{l}24.68 \% \\
(19 / 77)\end{array}$ & $\begin{array}{l}37.50 \% \\
(12 / 32)\end{array}$ & 2.77 & $\begin{array}{l}0.90- \\
8.52\end{array}$ & 1.83 & $\begin{array}{l}0.75- \\
4.48\end{array}$ & 1.47 & $\begin{array}{l}1.06- \\
2.06^{\mathrm{a}}\end{array}$ & 1.43 & $\begin{array}{l}0.98- \\
2.08\end{array}$ \\
\hline $\begin{array}{l}\text { Carrying objects } \\
>15 \mathrm{~kg}\end{array}$ & $\begin{array}{l}19.48 \% \\
(15 / 77)\end{array}$ & $\begin{array}{l}31.25 \% \\
(10 / 32)\end{array}$ & 2.51 & $\begin{array}{l}0.76- \\
8.22\end{array}$ & 1.88 & $\begin{array}{l}0.73- \\
4.85\end{array}$ & 1.54 & $\begin{array}{l}1.08- \\
2.19^{\mathrm{a}}\end{array}$ & 1.39 & $\begin{array}{l}0.95- \\
2.06\end{array}$ \\
\hline $\begin{array}{l}\text { Carrying objects } \\
>5 \mathrm{~kg},>10 \mathrm{~m}\end{array}$ & $\begin{array}{l}5.19 \% \\
(4 / 77)\end{array}$ & $\begin{array}{l}15.63 \% \\
(5 / 32)\end{array}$ & 2.08 & $\begin{array}{l}0.37- \\
11.76\end{array}$ & 3.38 & $\begin{array}{l}0.82- \\
13.91\end{array}$ & 1.19 & $\begin{array}{l}0.78- \\
1.82\end{array}$ & 1.23 & $\begin{array}{l}0.78- \\
1.92\end{array}$ \\
\hline $\begin{array}{l}\text { Kneeling and } \\
\text { squatting }\end{array}$ & $\begin{array}{l}3.90 \% \\
(3 / 77)\end{array}$ & $\begin{array}{l}3.13 \% \\
(1 / 32)\end{array}$ & 0.24 & $\begin{array}{l}0.02- \\
2.55\end{array}$ & 0.80 & $\begin{array}{l}0.08- \\
8.04\end{array}$ & 1.16 & $\begin{array}{l}0.78- \\
1.82\end{array}$ & 1.24 & $\begin{array}{l}0.75- \\
2.03\end{array}$ \\
\hline Stair climbing & $\begin{array}{l}35.06 \% \\
(27 / 77)\end{array}$ & $\begin{array}{l}43.75 \% \\
(14 / 32)\end{array}$ & 3.08 & $\begin{array}{l}1.05- \\
9.10^{\mathrm{a}}\end{array}$ & 1.44 & $\begin{array}{l}0.62- \\
3.36\end{array}$ & 1.26 & $\begin{array}{l}0.93- \\
1.72\end{array}$ & 1.04 & $\begin{array}{l}0.74- \\
1.48\end{array}$ \\
\hline
\end{tabular}




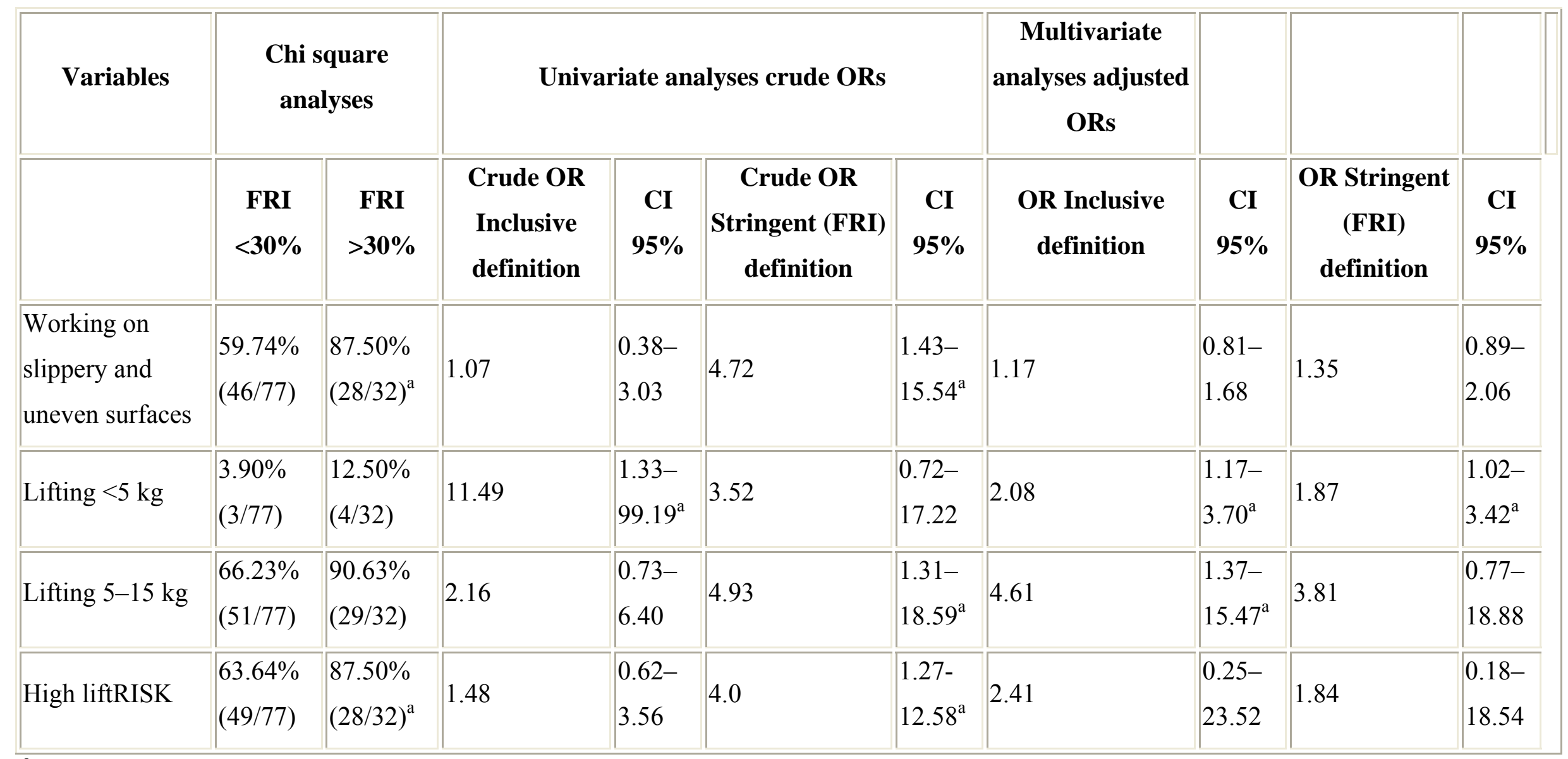

${ }^{\mathrm{a}} p \leq 0.05$. 
Chi-square analyses, of differences in exposure between workers with a FRI of $\geq 30 \%$ versus $<30 \%$, indicated significant differences $(p \leq 0.05)$ in $90^{\circ}$ trunk flexion, pushing and pulling, working on slippery and uneven surfaces and high lift risk variables. Multivariate analyses, using the inclusive definition (presence/absence of LBP) indicated various positive associations (Table 3$)$, with full forward bending $\left(90^{\circ}\right.$ trunk flexion) (OR 3.09; 95\% CI 1.49-6.41), bulky manual handling (OR 1.89; CI 1.173.08), single handed manual handling (OR 1.77; CI 1.09-2.89), unstable manual handling (OR 1.69; CI 1.04-2.75), carrying 5-15 kg objects (OR 2.57; CI 1.07-6.20), carrying objects $>15 \mathrm{~kg}$ (OR 1.54; CI 1.08-2.19), lifting $<5 \mathrm{~kg}$ objects (OR 2.08; CI 1.17-3.70) and lifting 5-15 kg objects (OR 4.61; CI 1.37-15.47) being statistically significant occupational risks.

Multivariate analyses, using the more stringent classification for LBP (FRI $\geq 30 \%$ ) yielded, however, only two statistically significant associations (Table 3 ). These were full forward bending (90 trunk flexion) (OR 2.16; 95\% CI 1.15-4.05), and lifting $>5 \mathrm{~kg}$ objects (OR 1.87; CI 1.02-3.42.

\section{Discussion}

\section{Prevalence}

Comparing prevalence and incidence rates of LBP with literature is subject to interpretation because of the various definitions of LBP. It is however interesting to note that the lifetime prevalence $(71.6 \%)$ of these workers is comparable with the $80 \%$ often quoted in literature. While $37.6 \%$ of the workers indicated to have some form of LBP at the time of data capturing, a fairly high proportion $(29.4 \%)$ of the workers seem to have more serious LBP, which limits their daily activities. These findings are in accordance with point prevalence rates of between 12 and 35\% mentioned in literature [2-5, 34-39]. The $29.4 \%$ of workers who perceive to have LBP, which limits their daily activities substantially, is, however, a point of concern for this specific industry. Another interesting observation is that such more severe LBP is more prevalent in the cell house workers than in the metal handling workers. The nature of the tasks for these workers is that of hard manual labor, compared to lighter work tasks of the metal handling house workers (Table 2). 
Trunk posture

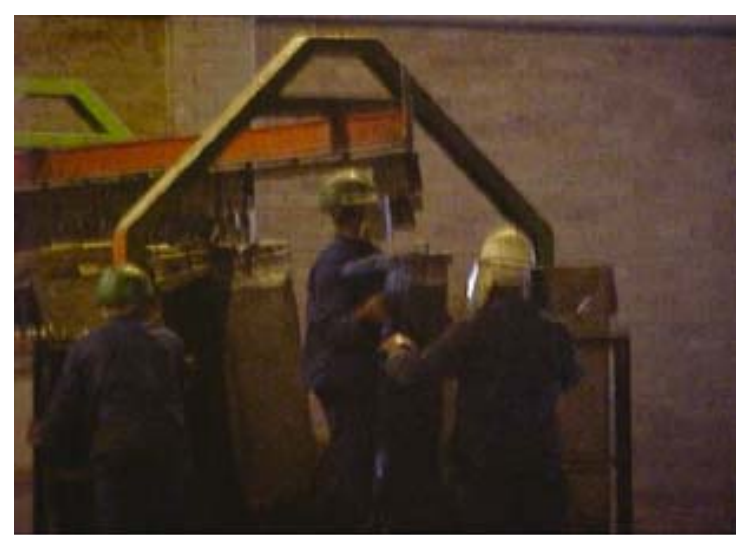

Fig. 1 Cell stripping

Prolonged trunk flexion was associated with LBP with adjusted odds of between 1.24 and 2.16, with full flexion $\left(90^{\circ}\right)$ indicating higher adjusted odds than slight flexion $\left(45^{\circ}\right)$. Trunk flexion in combination with twisting $\left(45^{\circ}\right)$ indicated an adjusted OR of 1.38 for the higher LBP disability group (FRI $>30 \%$ ). Various occupational tasks in this plant such as manual handling of the metal plates in the cell houses, working in the $\mathrm{KOB}$ and in the acid bath areas, all require frequent bending and twisting. For the majority of workers (77 out of the 109) in this factory, their main job task is that of cell stripping. Cell stripping involves the lifting of a plate of $20 \mathrm{~kg}$ out of a cell and hanging the plates on a monorail at a height of $2.45 \mathrm{~m}$. Two workers normally manage these tasks where one worker lifts the plates out of the cells, and the other worker assists in hanging the plates on the monorails (Fig. 1). These lifting actions require the worker to perform full flexion, from a $0 \mathrm{~cm}$ stooping height (Fig. 2). Because of the high frequency of lifting required (minimum 15/min), and the duration of the working shifts $(7.5 \mathrm{~h})$, the workers spend considerable periods of time in full and moderate spinal flexion. Secondary to the awkward position of full flexion, the neutral spine is lost more often than not, and that together with twisting can cause additional torsion forces on the spine [40]. The point prevalence in these 77 workers was also high with values of 40.26 and $36.36 \%$, using the inclusive and stringent classification of LBP respectively. 

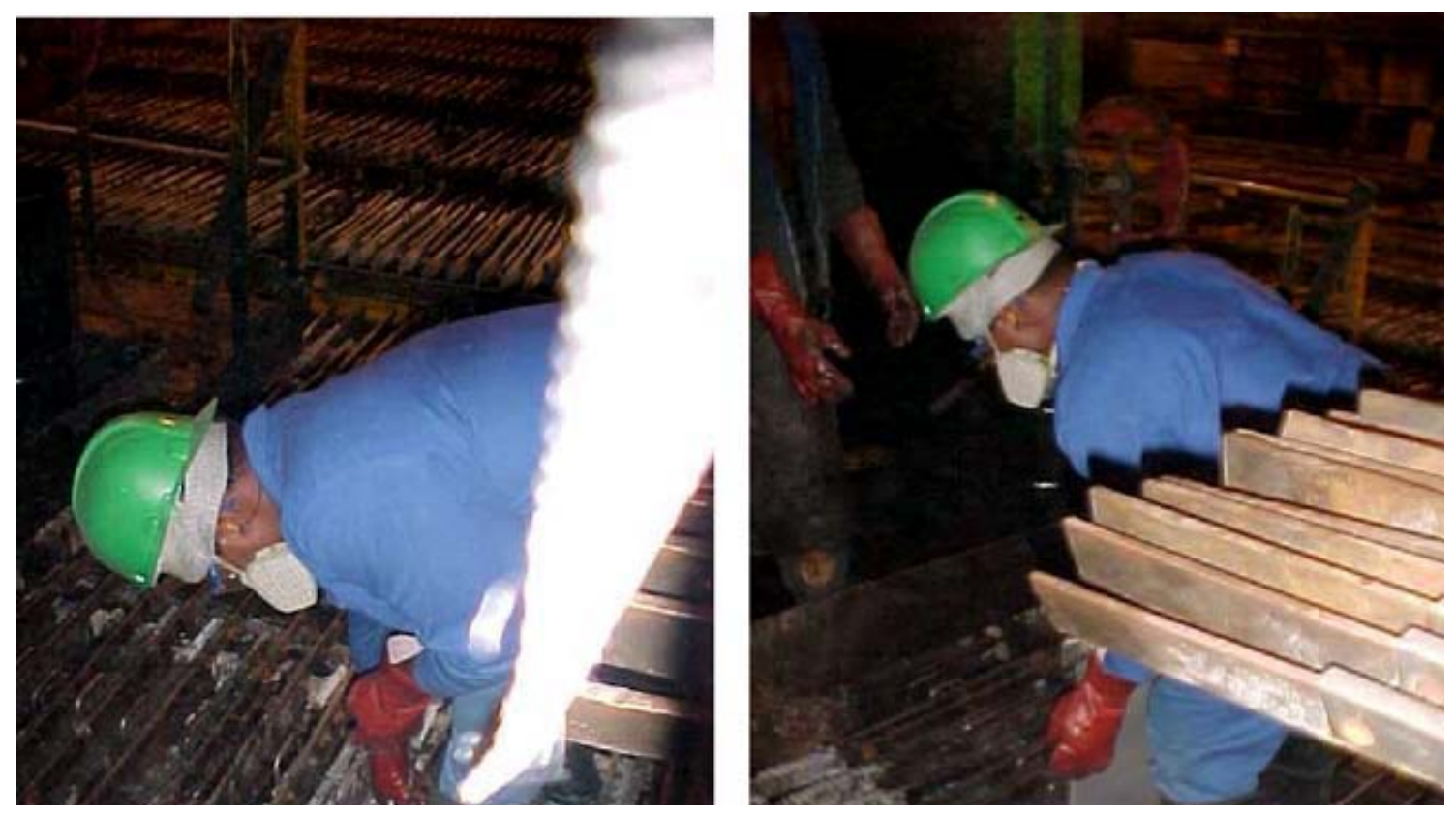

Fig. 2 Cell house worker stripping plates

Workers in the KOB areas also require full forward bending during certain movements (Fig. 3) Although not as frequent, as during cell stripping, it must be mentioned that most cell house workers rotate between work in the KOB areas, and stripping cells. Workers who indicated KOB work to be their primary work task had a point prevalence of $20 \%$ using both inclusive and stringent classifications of LBP. These findings are consistent with positive associations between flexion posture and LBP reported in literature $[19,41,42]$. The torsion forces that develop with combined twisting and flexion are well known $[9,40]$, and numerous studies have identified axial twisting of the torso as a significant risk factor for occupationally-related LBP [43-45]. Although trunk lateral velocity and trunk twisting velocity were not considered in this study, they need to be taken in consideration when assessing twisting and bending as a possible risk factor in the developing of LBP. Generating high torque while the spine is twisted appears to create a problematic combination and increases the risk for LBP [40]. 


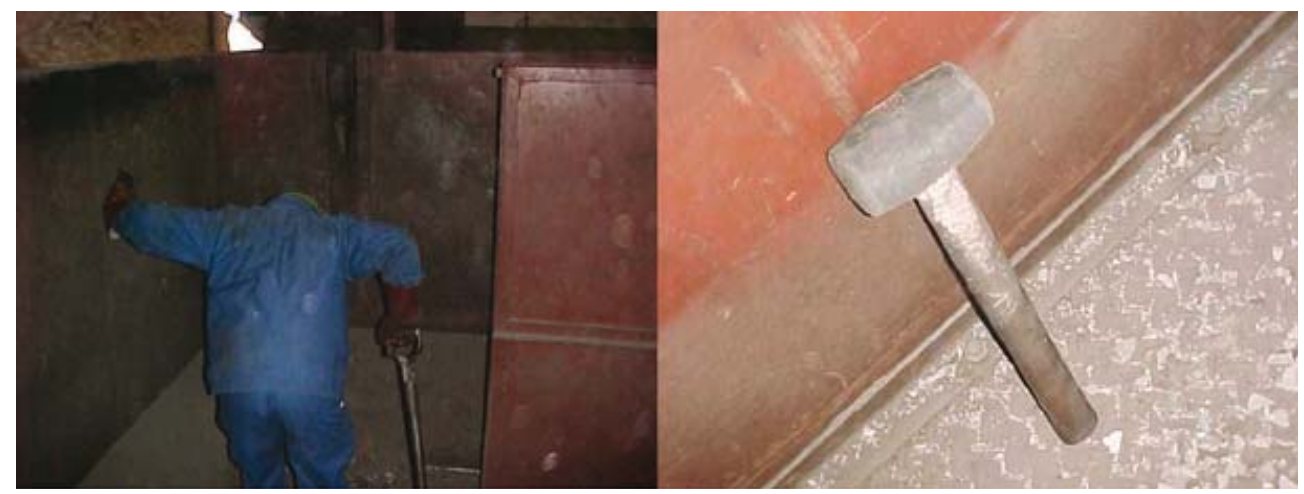

Fig. 3 KOB work and hammer used

\section{Stair climbing}

Stair climbing indicated a significant association (OR 3.08; CI 1.05-9.10) with the inclusive definition of LBP, in univariate analysis. A study by Perkins and co-workers [46] among pregnant women support these findings. A possible explanation for this observation could be related to the layout of the cell houses. These areas are built on 2 levels, which force the workers to use the staircases frequently in their daily work routine.

\section{Manual handling and load carriage}

Manual handling and load carriage was significantly associated with LBP with adjusted odds of between 1.47 and 1.89. These findings, are supported in literature by various authors who found manual handling and load carriage to be associated with LBP [47-49]. Although monorails are used in this factory to transport metal plates, it is occasionally required from the cell house workers to carry the plates from one cell to another or between the acid bath and the KOB area. This then, often leads to carriage of plates over distances, which support the possibility that load carriage over a distance could lead to more serious LBP [50]. This load carriage takes place over uneven and slippery surfaces, which may contribute to the risk attribution. Another point to consider is that these plates are often uncomfortable to handle, which leads the workers to carry the plates in non-ideal postures, which may again predispose to LBP.

\section{Lifting activities}

Lifting activities were associated with LBP with adjusted odds of between 1.87 and 4.61 (Table 3). This is not surprising, when considering the lifting frequency and 
lifting parameters (stooping and reaching distances) prevalent in the task of cell stripping. More than 11 times an hour was classified as exposure in the ORFQ, where most cell strippers lifting at a frequency of minimum 15 lifts per minute. These findings support the opinion of the NIOSH report [9], which in a critical review of 18 epidemiological studies, found 13 studies to be consistent in demonstrating a positive relationship between lower back disorders and work-related lifting and forceful movements. Our findings also support a South African study on musculoskeletal pain and workplace stressors in the South African automotive industry by Schierhout and co-workers [51], which found a total lifting score to be the only significant association with LBP.

A noteworthy observation was that most workers lift the plates out of the cells with straight legs (Fig. 2). That again raises the question of stooping versus squatting styles of lifting, which according to McGill [40] is still unresolved, despite much research comparing the two styles [52-56]. These workers do, however, use momentum to lift the plates, which is a recommendation for reducing spinal load when exerting a force, rather than always lifting slowly, which is an ill-founded recommendation for many skilled workers [40].

\section{Pushing and pulling}

Pushing and pulling indicated a significant association (OR 4.38; CI 1.16-16.45) with the more stringent classification for LBP, in univariate analysis. Various pushing and pulling actions occurs in the Manganese plant. As mentioned before, the majority $(n=77)$ of the labourers work in the cell houses and their main job task is to strip plates (Fig. 1), together with pushing plates on a monorail from the cell to KOB areas (Fig. 4). Cell stripping itself involves pulling actions to secure plates lifted from the cells. Because of the elevated height of the monorails above the pelvic area, pushing and pulling forces of sometimes 5-10 plates in combination (100-200 kg) pass by the spine with a large resistance moment arm, requiring large muscle forces and spinal loads [40]. Although velocities of motion and other biomechanical variables were not taken in consideration in this study, the self-reported perceived exposure to occupational risks of pushing and pulling activities is verified by the finding of a high prevalence of LBP in the cell house labourers. 


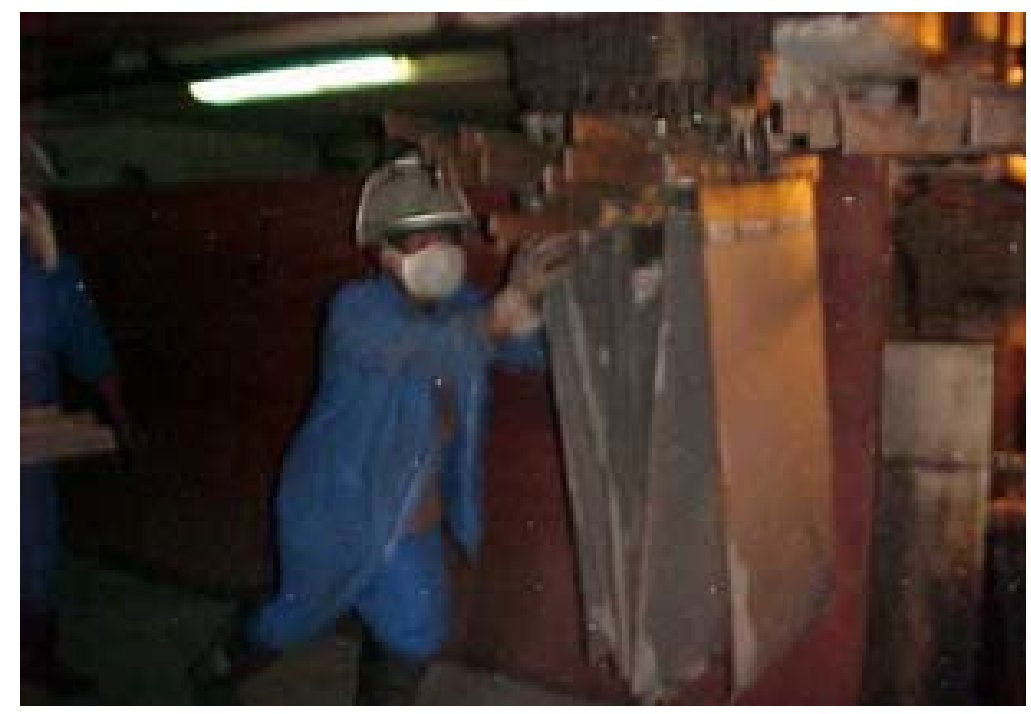

Fig. 4 Cell house worker pushing plates on a monorail

Hoozemans and co-workers [15], in their review on pushing and pulling concluded that epidemiological studies provide evidence that pushing and pulling are associated with low back pain when factors such as the load, distance, frequency, handling height, working method and worker characteristics are considered. Looking at the literature, the risk of pushing and pulling has not been studied as well as lifting and carrying, and generally epidemiological data available to answer the question of whether pushing and pulling is related to musculoskeletal complaints is inconclusive $[12,57,58]$.

\section{Environmental demands}

Working on slippery and uneven surfaces was associated with stringently defined cases of LBP (OR 4.72; CI 1.75-19.08), in univariate analysis. It is worth mentioning that the cell house workers in the factory are mainly working in an area where the floor surfaces are indeed slippery and uneven (Fig. 5). Literature is limited on this risk factor, but in most ergonomic guides one will find recommendations on tidy and clean work areas, to prevent slipping, especially during manual handling tasks. The risk of injury to the spine may also increase when loss of balance occurs during lifting [59], which tends to happen on slippery surfaces. This risk is compounded when workers are in the process of stripping plates and when manganese material covers the floor of the KOB areas (Fig. 3). 


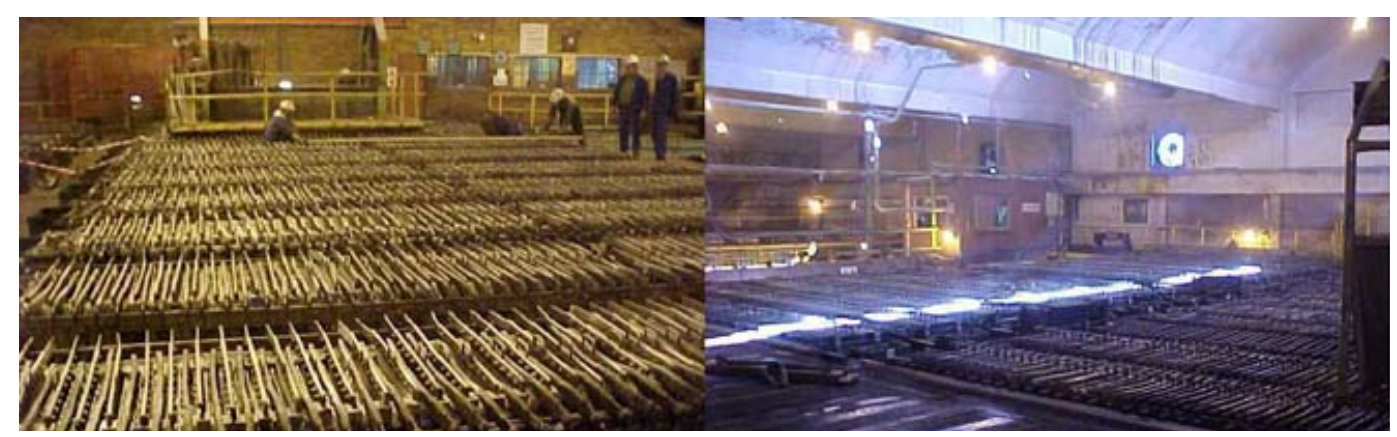

Fig. 5 Cell house working surfaces

Some measured risk factors did not show any significant associations with LBP, with some even indicating negative associations (Kneeling and squatting; OR 0.24-0.80 in univariate analysis). These findings vary from other cohorts [60]. One explanation could be that these workers seldom kneel or squat, while enhanced load capacity could be another. Considering the mean working exposure of $7.78 \pm 6.99$ years, the role of self-selection and work hardening may be in play. When considering NIOSH guidelines for lifting it is evident that demonstrated stooping height, reaching distances, and lifting frequency, a lifting index is in excess, thus indicting the role of self-selection and continuing performing the tasks at almost superhuman efforts. The healthy worker effect could also be applicable here.

There are some potential limitations to the study that need consideration. Firstly, cross-sectional research design necessitates caution with inferring causal paths.

Secondly, outcome was primarily based on self-reports and perceptions. Although these were subjective measures, validated measuring instruments were used, and the procedures followed also assured accurate, and reliable data.

A strong point of this specific study was the way in which occupational exposure was measured. One finds in studies with high subject numbers, that physical factors are typically measured at the group (e.g., job or task) level and often by observational methods with limited precision or accuracy. In this study self-reported occupational risk factors were assessed on an individual one to one basis, with a valid and reliable tool (ORFQ), together with observational analyses (liftRISK) to assess lifting related risk.

In this study we focused primarily on associations between self-reported occupational risk factors and inclusive and stringently defined point prevalence of LBP, and although a number of positive associations were found, relatively few statistically 
significant associations were found in this study. This could be ascribed to the size of the cohort, and/or the acquired loading capacity of the subjects. These findings further illustrate the specificity of every industrial setting, and confirm the necessity of regional and industry-specific studies in seeking preventative measures to decrease LBP. The findings also support multi-modal preventative approaches, which seem better than single-modal interventions.

It is further recommended that prospective studies will follow in the South African industrial setting to establish the temporal relationship between exposure and outcome. Studies on stooping versus squatting styles of lifting, more in-depth studies on pushing and pulling (load, distance, frequency, handling height) and studies on individual worker characteristics are also recommended.

\section{References}

1. Deyo RA. Low-back pain. Sci Am 1998;279:49-50.

2. Lee P, Helewa A, Goldsmith CH, Smythe HA, Stitt LW. Low back pain: prevalence and risk factors in an industrial setting. J Rheumatol 2001;28(2):34651.

3. Maniadakis N, Gray A. The economic burden of back pain in the UK. Pain 2000;84:95-103.

5. Zinzen E. Epidemiology: Musculoskeletal problems in Belgium nurses. In: Reily T, editor. Musculoskeletal disorders in health-related occupations. Ohmsha: IOS Press; 2002, p. 41-61.

6. Muller CF, Monrad T, Biering-Sorensen F, Darre E, Deis A, Krygegr P. The influence of previous lowback trouble, general health, and working conditions on future sick-listing because of low-back trouble. A 15-year follow-up study of risk indicators for self-reported sicklisting caused by low-back trouble. Spine 1999;24(15):1562-70.

7. Marras WS. Spine biomechanics, government regulation, and prevention of occupational low back pain. Editorial. Spine J 2001;1(3):163-5.

8. Volinn E. The Epidemiology of low back pain in the rest of the world: A review of surveys in low- and middle-income countries. Spine 1997;22(15):1747-54. 
9. NIOSH. Executive summary/Chapter 6: Low back and musculoskeletal disorders: evidence for work-relatedness. 1997. In: Bernard BP, editor. Musculoskeletal disorders (MSDs) and workplace factors/TOC. National Institute for Occupational Safety and Health, Cincinnati, OH; July 1997.

10. Volinn E, Spratt KF, Magnusson M, Pope MH. The Boeing prospective study and beyond. Spine 2001;26(14):1613-22.

11. Vowles KE, Gross RT. Work-related beliefs about injury and physical capability for work in individuals with chronic pain. Pain 2003;101(3):291-8.

12. Burdorf A, Sorock G. Positive and negative evidence of risk factors for back disorders. Scand J Work Environ Health 1997;23(4):243-56.

13. Hildebrandt VH. Back pain in the working population: prevalence rates in Dutch trades and professions. Ergonomics 1995;38(6):1283-98.

14. Hoogendoorn WE, van Poppel MNM, Koes BW, Bouter LM. Physical load during work and leisure time as risk factors for back pain. Scand J Work Environ Health 1999;25(5):387-403.

15. Hoozemans MJM, Van der Beek AJ, Frings-Dresen MHW, Van Dijk FJH, Van der Woude LHV. Pushing and pulling in relation to musculoskeletal disorders: a review of risk factors. Ergonomics 1998;41(6):757-81.

16. Lings S, de Leboeuf Y-C. Whole-body vibration and low back pain: a systematic, critical review of the epidemiological literature 1992-1999. Int Arch Occup Environ Health 2000;73:290-7.

17. Marras WS, Davis KG, Granata KP. Trunk muscle activities during asymmetric twisting motions. J Electromyogr Kinesiol 1998;8(4):247-56.

18. Marras WS, Davis KG, Jorgensen M. Gender influences on spine loads during complex lifting. Spine J 2003;3(2):93-9.

19. Punnett L, Fine LJ, Keyserling WM, Herrin GD, Chaffin DB. Back disorders and nonneutral trunk postures of automobile assembly workers. Scand J Work Environ Health 1991;17(5):337-46.

20. Snook SH, Ciriello VM. The design of manual handling tasks: revised tables of maximum acceptable weights and forces. Ergonomics 1991;34(9):1197-213. 
21. Solomonow M, Baratta RV, Banks A, Freudenberger C, Zhou BH. Flexionrelaxation response to static lumbar flexion in males and females. Clin Biomech 2003;18(4):273-9.

22. Toroptsova NV, Benevolenskaya CI, Karyakin AN, Sergeev IL, Erdesz S. "CrossSectional" Study of lower back pain among workers at an industrial enterprise in Russia. Spine 1995;20(3):328-32.

23. Walsh K, Varnes N, Osmond C, Styles R, Coggin D. Occupational causes of low back pain. Scand J Work Environ Health 1989;15(1):54-9.

24. Bigos SJ, Battie MC, Spengler DM, Fisher LD, Fordyce WE, Hansson TH, Nachemson AL, Zeh J. A longitudinal, prospective study of industrial back injury reporting. Clin Orthop 1992;279:21-34.

25. Vlaeyen JWS, Linton SJ. Fear-avoidance and its consequences in chronic musculoskeletal pain: a state of the art. Pain 2000;85:317-32.

26. Kraus JF, Gardner L, Collins J, Sorock G, Volinn E. Design factors in epidemiological cohort studies of work-related low back injury or pain. Am J Ind Med 1997;32:153-63.

27. Feise RJ, Menke JM. Functional rating index. A new valid and reliable instrument to measure the magnitude of clinical change in spinal conditions. Spine 2001;26(1):78-87.

28. Halpern M, Hiebert R, Nordin M, Goldheyden D, Crane M. The test-retest reliability of a new occupational risk factor questionnaire for outcome studies. Appl Ergon 2001;32(1):39-46.

29. Charteris J, Scott PA. LiftRISK User Manual. Rhodes University, South-Africa. October 1995. p. 1-25.

30. Kumar S, Narayan Y, Chouinard K. Effort reproduction accuracy in pinching, gripping, and lifting among industrial males. Int J Ind Ergon 1997;20:109-19.

31. Wiktorin C, Karlqvist L, Winkel J, Stockholm Music I Study Group. Validity of self-reported exposures to work postures and manual materials handling. Scand J Work Environ Health 1993;19:208-14.

32. Kelsey JL, Golden AL. Occupational and workplace factors associated with low back pain. Occup Med 1988;3(1):7-16. 
33. National Research Council. Work-related musculoskeletal disorders: review of the evidence. Washington, DC: National Academy Press; 1998. p. 17.

34. Deyo RA, Cherkin D, Conrad D, Volinn E. Cost, controversy, crisis: low back pain and the health of the public. Annu Rev Public Health 1991;12:141-56.

35. Frymoyer JW, Cats-Baril WL. An overview of the incidences and costs of low back pain. Orthoped Clin N Am 1991;22:263-71.

36. Loeser JD, Volinn E. Epidemiology of back pain. Neurosurg Clin N Am $1991 ; 2: 713-8$.

37. Scovron ML, Szalski M, Nordin M, Melot C, Cucier D. Socioeconomic factors and back pain. Spine 1994;19:129-37.

38. Waddell G. A new clinical model for the treatment of low back pain. Spine 1987;1:632-44.

39. Walsh K, Cruddas M, Coggon D. Low back pain in eight areas of Britain. J Epidemiol Community Health 1993;46:227-30.

40. McGill S. Low back disorders. Evidence-based prevention and rehabilitation. Champaign: Human Kinetics; 2002. p. 113-24; 161-84.

41. Burdorf A, Govaert G, Elders L. Postural load and back pain of workers in the manufacturing of prefabricated concrete elements. Ergonomics 1991;34(7):90918.

42. Hoogendoorn WE, Bongers PM, de Vet HCW, Douwes M, Koes BW, Miedema MC, Ariëns GAM, Bouter LM. Flexion and rotation of the trunk and lifting at work are risk factors for low back pain. Results of a prospective cohort study. Spine 2000;25(23):3078-92.

43. Kelsey JL, Githens PB, White AA, Holford TR, Walter SD, O'Connor T, Ostfeld, AM, Weil U, Southwick WO, Calogero JA. An epidemiologic study of lifting and twisting on the job and risk for acute prolapsed lumbar intervertebral disc. $J$ Orthop Res 1984;2(1):61-6.

44. Kahanovitz N. In: Diagnosis and treatment of low back pain. New York: Raven Press; 1991. p. 133-136.

45. Marras W, Lavender S, Leurgans S, Rajulu SL, Allread WG, Fathallah FA, Ferguson SA. The role of three-dimensional trunk motion in occupationally- 
related low back disorders: The effects of work-place factors, trunk position, and trunk motion characteristics on risk of injury. Spine 1993;18(5):617-28.

46. Perkins J, Hammer RL, Loubert PV. Identification and management of pregnancyrelated low back pain. J Nurse Midwifery 1998;43(5):331-40.

47. Erkintalo M, Salminen J, Alanen A, Paajanen H, Kormano M. Development of degenerative changes in the lumbar intervertebral disk: results of a prospective MR imaging study in adolescents with and without low-back pain. Radiology 1995;196:529-33. 
48. Grimmer K, Williams M. Gender-age environmental associates of adolescent low back pain. Appl Ergon 2000;31(4):343-60.

49. Reynolds KL, Kaszuba J, Mello RP, Patton JF. Prolonged treadmill load carriage: acute injuries and changes in foot anthropometry. Technical Report T1/91. Natick MA: US Army Research Institute of Environmental Medicine; 1990.

50. Lin Y, Chen C, Chen W, Cheng K. Characteristics of manual lifting activities in the patients with low-back pain. Int J Ind Ergon 2002;29(2):101-6.

51. Schierhout GH, Myers JE, Bridger RS. Musculoskeletal pain and workplace ergonomic stressors in manufacturing industry in South Africa. Int J Ind Ergon $1993 ; 12: 3-11$.

52. Adams MA, McNally DS, Chinn H, Dolan P. Posture and the compressive strength of the lumbar spine. Clin Biomech 1994;9:5-14.

53. Burgess-Limerick R. Squat, stoop, or something in between? Int J Ind Ergon 2003;31(3):143-8.

54. Garg A, Herrin G. Stoop or squat: A biomechanical and metabolic evaluation. Am Inst Ind Eng Trans 1979;11:293-302.

55. McGill SM, Kippers V. Transfer of loads between between lumbar tissues during the flexion relaxation phenomenon. Spine 1994;19(19):2190-6.

56. Potvin J, Norwin RW, McGill S. Reduction in anterior shear forces on the L4/L5 disc by the lumbar musculature. Clin Biomech 1991;6:88-96. 
57. Kuiper JI, Burdorf A, Verbeek JHAM, Frings-Dresen MHW, Van der Beek AJ, Viikari-Juntura E. Epidemiological evidence on manual materials handling as a risk factor for back disorders: a systematic review. Int J Ind Ergon 1999;24:389_ 404.

58. Van der Beek AJ, Hoozemans MJM, Monique HW, Frings-Dresen MHW, Burdorf A. Assessment of exposure to pushing and pulling in epidemiological field studies: an overview of methods, exposure measures, and measurement strategies. Int J Ind Ergon 1999;24(4):417-29.

59. Van der Burg JCE, van Dieën JH, Toussaint HM. Lifting an unexpectedly heavy object: the effects on low-back loading and balance loss. Clin Biomech 2000;15(7):469-77.

60. Harkness EF, Macfarlane GJ, Nahit ES, Silman AJ, McBeth J. Risk factors for new-onset low back pain amongst cohorts of newly employed workers. Rheumatology 2003;42:959-68. 